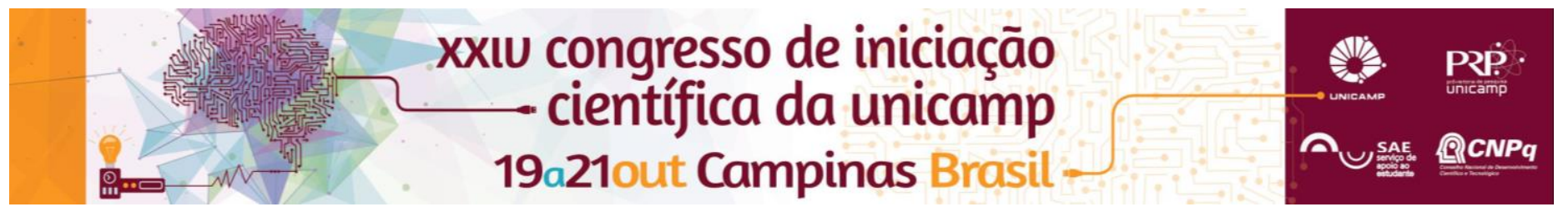

\title{
Proposta Metodológica de Ensino das Lutas
}

\author{
Adrielly Nascimento Silva*, Carolina Cirino, Larissa Rafaela Galatti.
}

\begin{abstract}
Resumo
As lutas, ao longo dos anos com todas as suas manifestações corporais, vêm sofrendo modificações (esportivização), onde as aulas, geralmente não são adequadas para crianças. Assim, observamos a importância de um currículo, para que qualquer profissional de Ciências do Esporte e Educação Física, possa administrar aulas de lutas a partir da Pedagogia do Esporte neste conjunto de modalidades. A partir da revisão de literatura - que busca investigar, localizar e analisar sobre trabalhos já realizados (MARCONI; LAKATOS, 2003) - partindo de lacunas da litaratura para promover uma proposta metodológicaque ofereça subsídios pedagógicos para o ensino das lutas no ambiente não formal de ensino. Este projeto de pesquisa está vinculado ao projeto de extensão Crescendo com as Lutas, realizado na FCAUNICAMP.
\end{abstract}

Palavras-chave:

Pedagogia do Esporte, Esporte de Combate, Jogos

\section{Introdução}

As lutas, inseridas na esfera da cultura corporal e com suas múltiplas possibilidades de práticas (RUFINO; DARIDO, 2015) vêm evoluindo de diferentes formas, junto com a história da humanidade, mostrando que sua criação não vem de uma ação isolada de um grupo, mas de uma construção sociocultural, que modifica-se ao logo do tempo (BREDA et al., 2010).

Pensando sobre o ensino das lutas, do seu inicio até atualmente, podemos concluir que as metodologias utilizadas não se diferem em alguns aspectos. Em seu princípio, as metodologias de ensino das lutas eram realizadas de uma maneira artesanal (DRIGO, 2007), com a formação dos faixas pretas e instrutores.

Partindo disso, vemos a importância do ensino das lutas em todos os âmbitos, principalmente de uma maneira adequada. Além de uma melhor capacitação dos futuros professores, desmistificando os preconceitos já existentes, facilitando o processo de ensino-aprendizagem, além da busca de uma pluralidade dentro do esporte.

Contudo, vemos a necessidade de sistematizar diretrizes para o ensino das lutas a partir dos jogos, possibilitando a qualquer professor, independente da sua especialidade, à competência para ensinar o conteúdo lutas, independente do seu âmbito de trabalho, pluralizando o ensino.

\section{Resultados e Discussão}

Devido à problemática do ensino tradicional ao se valorizar apenas os aspectos técnicos, não atendendo a realidade do combate (PINTO e SANTANA, 2007), ressaltamos a necessidade de fundamentar-se nos referenciais da Pedagogia do Esporte (MACHADO, GALATTI e PAES, 2015) sistematizando os conteúdos das lutas por níveis de complexidade e contatos com o oponente.

Os níveis tornam-se relevantes para unir as ações por sua complexidade, respeitando os conteúdos já agrupados por suas características semelhantes a partir do contato com o oponente, utilizando como estratégia pedagógica o contato mais próximo (contínuo) e evoluindo aumentando a distância do adversário (intermitente) até a inclusão de um implemento (com mediação) (GOMES et al., 2010; CIRINO, PEREIRA e SCAGLIA, 2013).

Do nível iniciante ao avançado, deveremos abordar no técnico-tático, habilidades básicas e específicas de cada DOI: 10.19146/pibic-2016-51576 contato, além de defesa e ataque simultâneo e oposição em diferentes aproximações; no socioeducativo a compreensão das regras e condutas da aula, discussão de valores a partir dos princípios filosóficos, ações e atitudes em benefício a todos e no histórico cultural faz se necessário a compreensão das saudações, cumprimentos, significados históricos, evolução das regras e discussão das diferentes manifestações das lutas atualmente e sua influencia na sociedade.

Posteriormente na aplicação do jogo pode observar-se que os conteúdos se unem, ou melhor, se complementam, sendo algo que somente o jogo pode proporcionar aos alunos, por meio de diferentes problemas e adversários, trazendo, assim, a realidade do combate para o jogador em contexto de jogo. Ademais, pelo jogo pode ocorrer a ressignificação de aspectos filosóficos e culturais, contribuindo para a formação integral do aluno (CIRINO; SCAGLIA; PEREIRA, 2013; OLIVIO JUNIOR e DRIGO,2015).

\section{Conclusões}

A sistematização mostrou-se pertinente, por compreender que as lutas é uma manifestação corporal e que pode ser trabalhada com uma metodologia pautada nos jogos, por criar múltiplas oportunidades de vivencias, algo que o ensino pode proporcionar. Contribuindo para o mesmo, o lúdico e os referenciais, torna o ensino amplo e integral, independente de onde será aplicado (projetos de iniciação esportiva, especialização e treinamentos em clubes e academias), no entanto, o objetivo não é criar modelos inflexíveis, mas, orientar para a construção do trabalho pedagógico, aplicado nas lutas.

\section{Agradecimentos}

Este projeto foi financiado pelo Conselho Nacional de Pesquisa e Tecnologia - CNPq, através do Programa Institucional de Bolsas de Iniciação Científica - PIBIC.

GOMES, M. S. P. et al. Ensino das lutas: dos princípios condicionais aos grupos situacionais Movimento, v. 16, n. 2, p. 207-227, 2010.

CIRINO, C.; SCAGLIA, A. J.; PEREIRA, M. P. V. DE C. Sistematização dos conteúdos das lutas para o ensino fundamental: uma proposta de ensino pautada nos jogos. Revista Mineira de Educação Física, v. Edição esp, n. 9, p. 221-227, 2013.

MACHADO, G. V.; GALATTI, L. R.; PAES, R. R. Pedagogia Do Esporte E Projetos Sociais: Interlocuções Sobre a Prática Pedagógica. Movimento, v. 21, n. 2, p. 405-418, 2015

PINTO, F. S.; SANTANA,W.C. Iniciação ao Futsal: as crianças jogam para aprender ou aprendem para jogar? (On-line). Disponível em: <www.pedagogiadofutsal com br> Acesso em: 16 mar. 2016.

OLIVIO JUNIOR, J. A.; DRIGO, A. J. Pedagogia complexa do Judô - um manual para treinadores de equipes de base. $1^{\circ}$ ed. Leme - SP: Mundo jurídico, 2015

MARCONI, M. A.; LAKATOS, E.M. Métodos científicos. In: Fundamentos de metodologia científica - 5. ed. - São Paulo : Atlas, 2003. p. 83- 112.

XXIV Congresso de Iniciação Científica da UNICAMP 